\title{
As consequências do neoliberalismo para a soberania alimentar haitiana e a produção da fome
}

\section{Consequences of neoliberalism for Haitian food sovereignty and famine production}

Beatriz Gomes Cornachin ${ }^{1}$

Dentre os países do continente americano, o Haiti configura o que apresenta maior índice em relação à desnutrição com aproximadamente metade da população dentro desse quadro. Não apenas no continente americano, mas também mundialmente o país configurou entre 2004 e 2006 o país com maior prevalência (57,1\%) e, no último período analisado, entre 2015 e 2017, apenas Zimbábue classifica-se com maior índice que o Haiti. Inserido na América Latina e Caribe, o país aponta como um caso necessário a ser evidenciado no tocante à questão alimentar, para além da atenção fundamental que a alimentação, independentemente de índices maiores ou menores, deve tomar. A região foi exemplo ao alcançar uma das metas dos Objetivos do Milênio, conseguindo reduzir pela metade o número de desnutridos. Infelizmente, nos últimos três anos, o inverso tem se colocado a partir do crescimento da desnutrição na região distanciando, portanto, dos atuais Objetivos do Desenvolvimento Sustentável. A partir disso, em pesquisa para dissertação de mestrado, buscou-se compreender quais as relações estabelecidas podem influenciar para o quadro de fome no Haiti. Renunciando inicialmente o determinismo geográfico, que frequentemente é utilizado pela mídia para justificar e naturalizar a fome não apenas no país, mas em outras regiões do mundo, partiu-se da compreensão de que tal flagelo tem origens multidimensionais, sendo que suas consequências são multifacetadas. A partir desse ponto inicial e de revisão bibliográfica sobre os tipos de fome e suas consequências, observou-se a utilização e evolução dos termos acerca da questão alimentar, tais como "segurança alimentar" e como esses podem ser angariados para, primeiro, justificar um comércio internacional de commodities e, segundo, intensificar a dependência alimentar de alguns países em relação a outros. Para tanto, fez-se primordial a abordagem a partir de uma perspectiva de soberania alimentar, evidenciando como esta tem relação com a própria dificuldade de soberania política do país. Partindo de tais constatações, se optou por compreender uma das implicações ocorrentes na questão alimentar: o comércio. Nesse sentido, o neoliberalismo apareceu como um divisor de águas durante a pesquisa. Medidas aplicadas a partir de 1980 implicaram uma ampla abertura de mercado, sendo que tarifas alfandegárias caíram de $35 \%$ para $3 \%$ em alguns produtos, dentre eles, o arroz. A partir de consultas no banco de dados da USDA, foi possível constatar que após a década de 1980, especificamente a partir de 1986, duas coisas ocorreram: o aumento do consumo doméstico de arroz e a consequente importação de arroz estadunidense. A principal problemática que se coloca é que esse arroz originário dos Estados Unidos da América é altamente subsidiado por Washington, resultando em um arroz mais barato que o local e também mais fácil de ser consumido, uma vez que os fazendeiros estadunidenses têm (além dos subsídios) algo que os haitianos não possuem: insumos agrícolas. 
Palavras-chave: fome; neoliberalismo; Haiti; soberania alimentar.

Keywords: hunger; neoliberalism; Haiti; food sovereignty.

1 Mestre em Ciências Humanas e Sociais pela Universidade Federal do ABC 